\title{
НАУКОВІ РОЗВІДКИ ХХІ СТОЯІТТЯ В ГАЯУЗІ МОРСЬКОЇ ОСВІТИ: ІСТОРИЧНИЙ АСПЕКТ ТА ПЕРСПЕКТИВИ
}

Стаття репрезентуе векторні напрями досліджень різноаспектних питань морської освіти як у військовому, так $i$ в цзивільному напрямах ї розвитку. Наголошено, що у ХХІ столітті превалюють дослідження, спрямовані на розкриття питань підготовки військових моряків, зокрема, офічерів тактичного й оперативного рівня; історико-педагогічні дослідження (історія становлення й розвитку морської освіти в Україні), менш чисельними є дослідження компаративного характеру.

Мета статті полягае в окресленні основних положень, репрезентованих дослідниками морської освіти з виокремленням напрямів науково-дослідницького пошуку в контексті вимог Морської доктрини Украӥни на період до 2035 року $і$ Пріоритетних напрямів наукових досліджень та науково-технічних (експериментальних) розробок НАПН Украйни Ha 2018-2022 pp.

Методологічну основу дослідження становлять основні положення теорії пізнання про єдність процесів, взаємовпливів та взаємозалежностей явищ навколишньої дійсності в конкретно-історичних умовах та комплекс взаємопов'язаних підходів (ццілісний, синергентичний, міждисцииплінарний, задачний, діяльнісний) $і$ взаємодоповнюваних методів (загальнонаукові, проблемно-тематичний, контент-аналіз, проєктування), зокрема, контент- аналіз, узагальнення, вивчення документації.

Наукова новизна дослідження полягае в окресленні векторних напрямів досліджень перспективних питань морської освіти військового і циивільного напрялів на основі здійснення ретроспективного контент-аналізу досліджень ХХІ століття.

Зроблено висновок, що перспективними є дослідження компаративного характеру як новий вектор наукового пошуку, що передбачае вивчення продуктивного досвіду розвинутих морських країн та / або країн, які перебуватоть на стадії похітичних та економічних трансформацій з метою виокремлення надбань, які доречно адаптувати для застосування увітчизняному освітньо-морському просторі; дослідження, спрямовані на розкриття комплексних проблем підготовки висококваліфікованих фахівців морського профілю в умовах прийняття нових державних стандартів вищої освіти, відповідних стратегій, концепцій, доктрин, які обумовлюють розвиток морської освіти і науки як військового, так і ццивільного напрямів.

Ключові слова: морська освіта, військово-морська освіта, наукові дослідження, військовий та цุивільний напрями, ретроспективний контент-аналіз.

Постановка проблеми. XXI століття характеризується актуалізацією досліджень 3 питань морської освіти як військової, так і цивільної. Актуалізація різноаспектної проблематики в останній рік пов'язана з обговоренням «Концепції Державної цільової науково-технічної програми відновлення морських досліджень та науково-дослідницької інфраструктури на період до 2025 року» [4], якою передбачено не дише відновдення досліджень моря, а й науково-дослідницької інфраструктури. Наголошено, що «науково-дослідницький та науково-освітній потенціал у сфері морських досліджень України в останні десятиріччя зменшився до мінімадьно критичного за всі роки незалежності України в силу різних причин, <...> практично припинилось проведення реальних регулярних експедиційних і польових досліджень в морській сфері» [там само]. Особливо важдивими в контексті положень Морської доктрини

*C) Терентьєва Н. О.

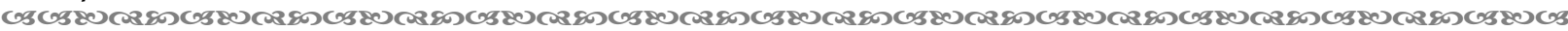
228 
України на період до 2035 року [5], яка визначає стратегію та основні напрями подальшого розвитку України як морської держави, $\mathrm{e}$ «відновлення та розвиток морегосподарського, морського оборонно-безпекового, морського наукового компдексу України» [4], зокрема, окрім цивільних досліджень, і спеціальних досліджень для ВМС щодо розвитку військово-морської діяльності та військово-морського потенціалу [5]. Схвалені у 2017 році Загальними зборами НАПН України «Пріоритетні напрями наукових досліджень та науково-технічних (експериментальних) розробок НАПН України на 2018-2022 рр.» передбачають, серед інших, дослідження розвитку світової і національних освітніх систем; методології, теорії, історії освіти і педагогіки; національної безпеки і безпеки життедіяльності [6], що охоплює дослідження морської тематики.

Аналіз досліджень. Дослідження підготовки військових моряків здійснюються переважно викладацьким складом вищих військово-морських закладів освіти. Зокрема, це дослідження В. Ворони, О. Злобіної, А. Аубенця, І. Попроцького, О. Чернявського, Р. Шевченко, В. Шемчука та ін. Частково така активізація наукових досліджень різноаспектної підготовки військових моряків (зокрема, офіцерів тактичного й оперативного рівня) пов'язана 3 прийняттям державних стандартів вищої освіти, якими окреслено обов'язковість здійснення наукової роботи та наукової підготовки курсантів у закладах вищої військової освіти висококваліфікованим професорськовикладацьким складом, який має бойовий досвід і наукові ступені. Таке поєднання є викдиком часу, особливо в країні, яка веде бойові дії, та високоякісна підготовка курсантів, відповідно, є одним 3 пріоритетних державних завдань, що зазначено у Стратегї̈ Військово-Морських Сил Збройних Сил Україні 2035 [9].

Питання різноаспектної підготовки морських фахівців цивільного профілю є предметом дослідження О. Даниленка, Д. Герганова, А. Аяшкевич, В. Рябухи, О. Тимофєєва, С. Шмалей, О. Чорного та ін.

Зауважимо, що дослідження цивільного профілю здійснюються в рамках професійних інтересів та напрямів діяльності дослідників - фахівців закладів вищої освіти морського спрямування і спрямовані на дослідження розвитку / формування комплексу фахових і загадьних компетентностей курсантів / слухачів відповідно до напряму / спеціальності, за якою здійснюеться їх підготовка. Важдиве місце посідають історико-педагогічні дослідження (історія становлення й розвитку морської освіти в Україні), менш чисельними є дослідження компаративного характеру це становить новий вектор наукового пошуку, який передбачає вивчення продуктивного досвіду розвинутих морських країн та / або країн, які перебувають на стадії політичних та економічних трансформацій $з$ метою виокремлення надбань, які доречно адаптувати для застосування у вітчизняному морському (освітньо-морському) просторі.

Мета статті полягає в окресленні основних положень, репрезентованих дослідниками морської освіти 3 виокремленням напрямів науково-дослідницького пошуку в контексті вимог Морської доктрини України на період до 2035 року та Пріоритетних напрямів наукових досліджень та науково-технічних (експериментальних) розробок НАПН України на 2018-2022 рр.

Виклад основного матеріалу. За останні роки дослідження морської тематики активізувадись в історико-педагогічній та професійно-педагогічній галузі. Здійснимо контент-аналіз окремих досліджень задля виокремлення перспективних напрямів їх подальшого здійснення. Серед захищених дисертаційних досліджень виокремимо роботи О. Даниленка («Система неперервної підготовки майбутніх судноводіїв у вищих морських навчальних закладах», 2020) [1], В. Золотовської («Тенденції вивчення іноземних мов у вищих навчальних закладах морського профілю (70-ті роки XXпочаток XXI ст.)», 2019) [2], А. Аяшкевич («Теорія і практика морської освіти півдня України (30-ті роки XIX - початок XXI століття)», 2019) [3], І. Рябухи («Тенденції розвитку морської освіти в Україні (друга половина XVIII - початок XXI століття)», 2019) [7], 
А. Солодовник («Розвиток фізико-математичної підготовки у морських навчадьних закладах України (1944-2012 рр.)», 2018) [8] та ін.

Основними авторськими здобутками визначаємо:

1) обгрунтування «...теоретичних засад розвитку морської освіти на півдні України в період із 30-х років XIX до початку XXI століття; метододогічних підходів (системний, структурно-функціональний, історико-хронологічний, конкретно-історичний, синергетичний, просторово-середовищний) 3 урахуванням закономірностей..., принципів (об'єктивності, науковості, історизму, детермінізму, багатофакторності) і методів...» [3, с. 37]; розкриття «...наскрізних змістових лінії розвитку морської освіти: поєднання європейських та українських традицій, залежність організації морської освіти від суспільно-економічних потреб і умов південного регіону та країни в цілому, а їі змісту - від рівня науково-технічного розвитку, ідеолого-педагогічної доктрини та державної підтримки; виокремлення структурних компонентів морської освіти (цільовий, змістовний, нормативно-правовий, операційно-діяльнісний, мотиваційний, оцінно-результативний) як процесу та як соціально-педагогічної системи <...> [там само]; визначення «...рушійних сид і чинників, що впливали на розвиток морської освіти на півдні Україні: соціально-економічні (державні інтереси, розвиток науки і техніки, національна безпека, особистий приклад), суспільно-політичні (розпорошеність відомчого підпорядкування, дуальність в управлінні, національна безпека), організаційно-педагогічні (розширення спеціалізації підготовки за фахом та типом флоту, професійна нащадковість, патріотичне виховання, комплексність функціонування закладів у закритому режимі), галузево-технологічні та регіональні (географічне поширення від периферії - півдня - до центру, розгалужена виробнича база, змішане фінансування 3 широким представленням меценатства)...» [3, с. 37-38]; обгрунтування авторської періодизації 3 характеристикою «..основних тенденцій становлення й розвитку морської освіти на півдні України в 30-ті роки XIX - на початку XXI століть з урахуванням суспільно-політичних, економіко-правових та педагогічних детермінант: 1) стихійно-установчий (1830-ті - друга половина 1850-х рр.) - точкове виникнення осередків освітньо-професійного середовища морської освіти за відсутності єдиної програми ії становлення, 2) перший реформаторський (друга половина 1850-х початок 1870-х рр.) - зміна змісту діяльності закладів морського профілю, спричинена втратою впливу на Чорноморському басейні (наслідки Кримської війни), 3) другий реформаторський (початок 1870-х - початок 1900-х рр.) - побудова системи морської освіти на базі нової інструктивно-правової бази, 4) законодавчий (початок 1900-х 1920 рр.) - спроба сформувати законодавчу базу морської освіти як скдадно структуровану частину професійної (у періоді виокремлено паузу 1917-1920 рр., коли на півдні України відбувалася іноземна інтервенція і громадянська війна), 5) пошуковоуніфікаційний (1920-1991рр.) - пошук нового організаційно-педагогічного підгрунтя морської освіти (через відмову від досвіду минулого) із наступною стандартизацією системи підготовки фахівців для торгівельного флоту, 6) наслідувально-оновлювальний (1991-2013 рр.) - розбудова національної, якісно нової системи морської освіти на основі синтезу продуктивного досвіду минулого, сучасних інновацій (технічних, управлінських, педагогічних) та національних традицій (3 паузою 1991-1995 рр.)» [3, с. 37-38]; «...уточнення передумов регіональної специфіки розвитку морської освіти на півдні України відповідно до сучасних міжнародних вимог та потреб держави; роль і вплив посадових осіб різного рівня на розвиток системи морської освіти на півдні України в період із початку XIX до початку XXI століття...» [там само];

2) здійснення «...компдексного досдідження розвитку морської освіти в Україні другої половини XVIII - початку XXI століття як наукового феномена і соціальноекономічного явища 3 виявленням глобальних (інтеграція освіти, науки і виробничої бази морської галузі; розширення економічної і міжкультурної взаємодії; зростання чисельності осіб, що здобувають морську освіту; збільшення рівня фінансування; us 230 
транснаціоналізація навчання морським професіям; зростання обсягів обміну фахівцями в освітній та водогосподарській галузях; утвердження механізмів управління розвитком освіти; формування і збереження спільного змістовного ядра морської освіти, наявність якого уможливила транснаціональну підготовку фахівців для флоту; упровадження принципів неперервної морської освіти; поширення дуальної системи морської освіти як складової професійної; збагачення діапазону форм і методів здобуття морської освіти; зростання автономності функціонування морських навчальних закладів iз поступовим перетворенням їх на навчально-методичні центри;) i локальних (континентальні, державні, регіональні, об'єктно-галузеві, індивідуально-особові) тенденцій іï розвитку...» [7, с. 7]; виокремлення «...иокальних тенденцій: поєднання зарубіжного і вітчизняного досвіду в організації та функціонуванні структур системи морської освіти; формування законодавчої та нормативно-правової бази водогосподарської й освітньої гадузей на підгрунті європейського та міжнародного досвіду; залучення громадськості до розв'язання проблем морської освіти; зростанні роді навчальних закладів у формуванні освітньо-культурного середовища (міста, регіону); переважання державного сектора в забезпеченні морського і водного транспорту; надання пріоритету практичній складовій у підготовці фахівців для флоту; науково-професійна творчість викладачів як механізм розвитку морського навчального закладу...> [7, с. 7]; виявлення «...загальних спільних рис (розширення мережі та спеціалізації морських навчальних закладів, детермінування змісту освіти науковотехнічним прогресом i політичною ситуацією, поєднання державного підходу до виховання морських офіцерів із родинно-професійною спадкоємністю) та особливостей (геополітична значущість території, наявність національних традицій у будуванні та експлуатації кораблів, тісний зв'язок територіальної цілісності та економічного розвитку країни 3 якістю морської освіти, наявність місцевого компонента в навчальних планах морських закладів, особистісно-професійна мотивація діяльності суб'єктів морської освіти) розвитку морської освіти в Україні...» [там само, с. 7-8]; розроблення «...3 урахуванням суспільно-політичних, економічних та педагогічних детермінант періодизацію розвитку морської освіти в Україні у другій половині XVIII - початку XXI століття: I період (друга половина XVIII століття - кінець 1910-х) - становлення і розвиток морської освіти на українських землях в імперську добу; II період (1910-ті - 1991) - розвиток морської освіти у межах системи професійної освіти СРСР; III період (1991-2010) - розбудова системи морської освіти в незалежній Україні...» [там само]; «...уточнення змісту національних традицій і роль конкретних історичних осіб у функціонуванні й розвитку морської освіти в Україні на вказаному історичному відрізку» [7, с. 8];

3) здійснення «...комплексного дослідження генези фізико-математичної підготовки в морських навчальних закладах України у 1944-2012 рр.; виокремлення структурних компонентів фізико-математичної підготовки курсантів морських навчальних закладів як педагогічної системи (інтеракційний, змістовий, темпоральний, функціонально-цільовий, технологічно-організаційний та контрольнорезультативний)...>» [8, с. 4]; обгрунтування «...авторської періодизації розвитку фізикоматематичної підготовки в морських навчальних закладах України в 1944-2012 рр.: І період (1944-1960 рр.) - установчо-відновдювальний; II період (1961-1992 рр.) теоретико-пошуковий (адаптаційно-політехнічний (1961-1965 рр.), модернізаційнотехнологічний (1966-1984 рр.), комп'ютеризаційно-перебудовчий $\quad$ (1985-1992 pр.)); III період (1993-2012 рр.) - реформаційно-імплементаційний (стандартизаційногуманітаризаційний (1993-2007 рр.), творчо-інтеграційний (2008-2012 рр.))...» [8, с. 4]; «...розкриття особливостей (актуальність переходу від суб'єкт-об'єктної до суб'єктсуб'єктної інтеракції викладачів і курсантів; визначення змісту фізико-математичної підготовки керівними органами влади протягом перших двох періодів та автономія морських навчальних закладів щодо вирішення цього питання в межах галузевих us 231 
стандартів вищої освіти впродовж останнього періоду; трансформація функціональноцільового компонента фізико-математичної підготовки 3 упровадженням компетентнісного підходу; еводюція іiі форм, методів і засобів від традиційних до інноваційних)» $[8$, с. 4];

4) окреслення «...тенденцій вивчення іноземних мов у закладах вищої освіти морського профілю у 70-х роках XX - на початку XXI століття: парадигмальні (оновлення змісту іншомовної професійної підготовки відповідно до пріоритетних напрямків розвитку морської галузі); структурно-навчальні (забезпечення оптимального вивчення іноземної мови у структурно-логічній схемі підготовки майбутніх фахівців морської галузі); змістові (кореляція змісту іншомовної підготовки зі специфікою професійної діяльності майбутніх фахівців морської галузі); інструментально-методичні (розвиток методичного інструментарію викладання іноземних мов у закладах вищої освіти морського профілю)» [2, с. 4]; обгрунтування «...періодизації вивчення іноземних мов у закладах вищої освіти морського профілю у 1970-ті роки XX - на початку XXI століття: I період (1978-1990рр.) - уніфікаційний; II період (1991-2002 рр.) трансформаційний; III період (2003-2017рр.) - інтеграційний» [2, с. 4-5]; виявлення «...чинників впливу на розвиток іншомовної професійної підготовки майбутніх фахівців морської галузі: соціально-економічні (орієнтація на потреби ринку праці, інтеграція в міжнародний простір, науково-технічний прогрес); освітні (оновлення нормативноправових документів у галузі освіти, стандартизація змісту підготовки, розвиток методик формування професійно-орієнтованого мовлення); галузеві (модернізація устаткування морських суден, розширення виробничих функцій фахівців морської галузі, інтернаціоналізація складу екіпажу суден)...» [там само].

Серед професійно-педагогічних досліджень виокремлюємо питання ступеневої підготовки майбутніх фахівців морської сфери, дослідженням яких у цивільних моряків - судноводіїв займається О. Даниленко [1], у майбутніх офіцерів тактичного рівня ВМС ЗСУ - Р. Шевченко.

\section{Висновки.}

1. Ретроспективний контент-аналіз здійснених історико-педагогічних досліджень засвідчив різнобічне висвітлення історичного розвитку морської освіти в Україні, зокрема іï цивільного сектору. Активно здійснюються наукові розвідки професійнопедагогічного напряму підготовки морських фахівців за спеціальностями у закладах вищої морської освіти як цивільного, так і військового профілів підготовки.

2. Перспективними є дослідження компаративного характеру як новий вектор наукового пошуку, що передбачає вивчення продуктивного досвіду розвинутих морських країн та / або країн, які перебувають на стадії подітичних та економічних трансформацій 3 метою виокремлення надбань, які доречно адаптувати для застосування у вітчизняному освітньо-морському просторі; дослідження, спрямовані на розкриття комплексних проблем підготовки висококваліфікованих фахівців морського профілю в умовах прийняття нових державних стандартів вищої освіти, відповідних стратегій, концепцій, доктрин, які обумовдюють розвиток морської освіти і науки як військового, так і цивільного напрямів. Перспективами вбачаємо здійснення наукових розвідок в окреслених напрямах.

\section{Список використаних джерел:}

1. Даниленко О. В. Система неперервної підготовки майбутніх судноводіїв у вищих морських навчальних закладах: дис... д-ра пед. наук : 13.00.04. Хмельницький, 2020. 527 с.

2. Золотовська В. С. Тенденції вивчення іноземних мов у вищих навчальних закладах морського профілю (70-ті роки XX- початок XXI ст.): автореф. дис ... канд. пед. наук : 13.00.01. Тернопіль, 2019. 20 с.

3. Ляшкевич А. І. Теорія і практика морської освіти півдня України (30-ті роки XIX - початок XXI століття: дис... д-ра пед. наук : 13.00.01. Херсон; Тернопіль, 2019. 573 с. 
4. $\mathrm{MOH} \mathrm{пропонує} \mathrm{для} \mathrm{громадського} \mathrm{обговорення} \mathrm{проєкт} \mathrm{розпорядження} \mathrm{КМУ} \mathrm{«Про} \mathrm{схвалення}$ Концепції Державної цільової науково-технічної програми відновлення морських досліджень», 2020. URL : https://mon.gov.ua/ua/news/mon-proponuye-dlya-gromadskogoobgovorennya-proyekt-rozporyadzhennya-kmu-pro-shvalennya-koncepciyi-derzhavnoyicilovoyi-naukovo-tehnichnoyi-programi-vidnovlennya-morskih-doslidzhen

5. Постанова КМУ від 18.12.2018 № 1108 «Про внесення змін до Морської доктрини України на період до 2035 року». URL : https://www.kmu.gov.ua/npas/pro-vnesennya-zmin-do-morskoyidoktrini-ukrayini-na-period-do-2035-roku

6. Пріоритетні напрями (тематика) наукових досліджень та науково-технічних (експериментальних) розробок Національної академії педагогічних наук України на 20182022 pp. URL : http://naps.gov.ua/ua/press/announcements/1315/

7. Рябуха I. М. Тенденції розвитку морської освіти в Україні (друга половина XVIII - початок XXI століття): автореф. дис … д-ра пед. наук : 13.00.01. Тернопіль, 2019. 35 с.

8. Солодовник А. О. Розвиток фізико-математичної підготовки у морських навчальних закладах України (1944-2012 рр.): автореф. дис ... канд. пед. наук : 13.00.01. Тернопіль, 2019. $18 \mathrm{c}$.

9. Стратегія Військово-Морських Сил Збройних Сил Україні 2035. URL : https://navy.mil.gov.ua/strategiya-vijskovo-morskyh-syl-zbrojnyh-syl-ukrayiny-2035/

\section{References:}

1. Danylenko, O. V. (2020). Systema neperervnoi pidhotovky maibutnikh sudnovodiiv u vyshchykh morskykh navchalnykh zakladakh [The system of continuous training of future navigators in higher maritime educational institutions]. (Doctor's thesis). Khmelnytskyi [in Ukrainian].

2. Zolotovska, V.S. (2019). Tendentsii vyvchennia inozemnykh mov u vyshchykh navchalnykh zakladakh morskoho profiliu (70-ti roky XX - pochatok XXI st.) [Trends in studying foreign languages in higher educational institutions of marine profile (70 years of XX - early XXI centuries)]. (Extended abstract of candidate's thesis). Ternopil [in Ukrainian].

3. Liashkevych, A. I. (2019). Teoriia i praktyka morskoi osvity pivdnia Ukrainy (30-ti roky XIX - pochatok XXI stolittia [The theory and practice of marine education in the south of Ukraine (30 years of the XIX - early XXI century]. (Doctor's thesis). Kherson; Ternopil [in Ukrainian].

4. The Ministry of Education and Science proposes for public discussion a draft order of the Cabinet of Ministers "On approval of the Concept of the State Targeted Scientific and Technical Program for the Restoration of Marine Research". (2020). Retrieved from https://mon.gov.ua/ua/news/monproponuye-dlya-gromadskogo-obgovorennya-proyekt-rozporyadzhennya-kmu-pro-shvalennyakoncepciyi-derzhavnoyi-cilovoyi-naukovo-tehnichnoyi-programi-vidnovlennya-morskihdoslidzhen [in Ukrainian].

5. Resolution of the Cabinet of Ministers dated December 18, 2018 No. 1108 "On amendments to the Maritime Doctrine of Ukraine for the period up to 2035". (2018). Retrieved from https://www.kmu.gov.ua/npas/pro-vnesennya-zmin-do-morskoyi-doktrini-ukrayini-na-period-do2035-roku [in Ukrainian].

6. Priorytetni napriamy (tematyka) naukovykh doslidzhen ta naukovo-tekhnichnykh (eksperymentalnykh) rozrobok Natsionalnoi akademii pedahohichnykh nauk Ukrainy na 20182022 rr. [Priority directions (topics) of scientific research, scientific and technical (experimental) developments of the National Academy of Pedagogical Sciences of Ukraine for 2018-2022]. (2017). Retrieved from http://naps.gov.ua/ua/press/announcements/1315/[in Ukrainian].

7. Riabukha, I. M. (2019). Tendentsii rozvytku morskoi osvity v Ukraini (druha polovyna XVIII - pochatok XXI stolittia) [Trends in the development of maritime education in Ukraine (second half of the seventeenth - early twenty-first century)]. (Extended abstract of Doctor's thesis). Ternopil [in Ukrainian].

8. Solodovnyk, A. O. (2019). Rozvytok fizyko-matematychnoi pidhotovky u morskykh navchalnykh zakladakh Ukrainy (1944-2012 rr.) [Development of physical and mathematical training in maritime educational institutions of Ukraine (1944-2012)]. (Extended abstract of candidate's thesis). Ternopil [in Ukrainian].

9. Stratehiia Viiskovo-Morskykh Syl Zbroinykh Syl Ukraini 2035. [Navy Strategy of the Armed Forces of Ukraine 2035]. Retrieved from https://navy.mil.gov.ua/strategiya-vijskovo-morskyh-sylzbrojnyh-syl-ukrayiny-2035/ [in Ukrainian]. 
Terentieva N. A., orcid.org/0000-0002-3238-1608

\title{
SCIENTIFIC EXPLORATIONS OF THE XXI CENTURY IN THE FIELD OF MARITIME EDUCATION: HISTORICAL ASPECT AND PERSPECTIVES
}

The article represents vector directions of researches of various aspects of maritime education both in military and civilian areas of its development. It is emphasized that researches aimed at revealing the issues of training sailors, in particular, officers of the tactical and operational level; historical and pedagogical researches (history of formation and development of maritime education in Ukraine) prevail in the XXI century, studies of a comparative character are less numerous.

The purpose of the article is to outline the main provisions represented by the researchers of maritime education, highlighting areas of research in the context of the Maritime Doctrine of Ukraine by 2035 and the Priority directions of scientific researches and scientific and technical (experimental) developments of the National Academy of Sciences of Ukraine for 2018-2022.

The main provisions of the cognitive theory about the unity of processes, interactions, and interdependencies of environmental phenomena in specific historical conditions and a set of interrelated approaches (holistic, synergistic, interdisciplinary, task, activity) and complementary methods (generalscientific, thematic, content analysis, designing), in particular, content analysis, generalization, the study of documentation, comprise the methodological basis of the study. The scientific novelty of the study is to outline the vector directions of the researches of perspective issues of maritime education in military and civilian fields based on a retrospective content analysis of the researches in the XXI century.

It is concluded that comparative researches are perspective as a new vector of scientific research, which involves studying the productive experience of the developed maritime countries and/or countries undergoing political and economic transformations to identify assets that should be adapted for use in native education and marine space; researches aimed at revealing the complex problems of training highly qualified specialists in the maritime profile in the adoption of new state standards of higher education, relevant strategies, concepts, doctrines that determine the development of maritime education and science in both military and civilian fields.

Key words: maritime education, naval education, scientific researches, military and civilian areas, retrospective content analysis.

Дата надходження статmі: 19.01.2021 p.

Рецензент: доктор педагогічних наук, професор Міненок А. О.

\author{
У,К 811:378.6 \\ DOI https://doi.org/10.37915/pa.vi48.205
}

Трибулькевич К. Г., orcid.org/0000-0002-1907-7011

\section{ДО ПИТАННЯ СТАНОВЛЕННЯ МОРСЬКОЇ ОСВІТИ В УКРАЇНІ}

У статті здійснено порівняльний аналіз підготовки фахівців у закладах вищої освіти морського профілю сучасного періоду та визначено основні тенденції у їх підготовц̧і.

Вивчення функціонування мережі закладів вищеӧ освіти морського профілю сучасного періоду дозволяе визначити спільні напрями підготовки фахівців: кораблебудування, суднові енергетичні установки, теплоенергетика (Одеський національний морський університет, Національний університет кораблебудування імені адмірала Макарова) автоматика та електротехніка, морське право, менеджмент, економіка (Національний університет

*(C) Трибулькевич К. Г.

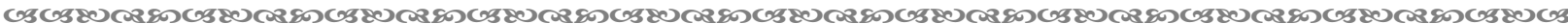
234 